\title{
LEADING CO-CREATION IN MULTI-DISCIPLINARY APPLIED PROJECTS
}

\author{
Richard ELAVER ${ }^{1}$, Dries LAPERRE ${ }^{2}$, and Mark LEWIS ${ }^{3}$ \\ ${ }^{1,3}$ Appalachian State University, North Carolina, USA \\ ${ }^{2}$ Howest University College, Kortrijk, Belgium
}

\begin{abstract}
In moving 'Towards a New Innovation Landscape', the premise of this paper is that the field of product design needs to more regularly engage design students with other disciplines and broaden the application of product design skills into more diverse arenas of creative problem solving. Beyond the design of products, design can be a more integrative skillset, design thinking a creative-problem-solving tool for diverse groups, and design communication tools (sketches, models, storyboards, etc.) can act as prototyping tools to help express and explore ideas in wide-ranging contexts.

This paper will introduce how this type of pedagogical approach has been applied in two different institutions: Howest University College in Belgium, and Appalachian State University in the USA. It will detail the different approaches these two schools have used to construct trans-disciplinary learning opportunities, along with a profile of the participants, resources, and methods utilised. This will provide a structure to compare and contrast different approaches used on different continents in order to draw conclusions regarding positive and negative outcomes.

From this, the hope is that other educators, in product design and other disciplines, can learn from these efforts and continue a discourse about how to develop graduates who can effectively tackle the multidisciplinary wicked challenges of the future.
\end{abstract}

Keywords: Trans-disciplinary, multi-disciplinary, co-creation, team learning, design thinking, projectbased learning, team organisation

\section{INTRODUCTION}

Much of academic training is focused within individual domains, concerned with inducting newcomers into an existing body of knowledge. In the field of product design, like many others, this has become particularly important because of the depth of technical know-how that needs to be developed in order for graduates to be effective professionals.

In an ever more interconnected world, faced with ever more complex challenges, domain specificity is no longer enough to survive and thrive. We need more professionals that excel at working across disciplines, tackling the wicked challenges that exist in the overlapping space between diverse fields of expertise. Additionally, there is a gap between what employers are looking for and what universities are producing in their graduates. Beyond technical competency, employers are looking for graduates with the capacity to address unstructured problems, to collaborate effectively in teams, and to have a high level of adaptability [1].

We believe that the field of product design is uniquely positioned to bridge disciplines, integrate diverse fields of expertise in solving wicked problems, and, most importantly, to facilitate others' skill development in trans-disciplinary collaboration. Our premise, then, is that the field of product design needs to more regularly engage design students with other disciplines and broaden the application of product design skills into more diverse arenas of creative problem solving. This is for the mutual benefit of design students deepening their capacity for trans-disciplinary work, and for those from other fields to learn from design in the areas of collaborative problem solving and design thinking methodology. In doing this, we can promulgate design as a more integrative skillset, spread design thinking as an effective creative problem-solving tool for diverse groups, and disseminate design communication methods as prototyping tools to help others express and explore problems and solutions in diverse contexts. 
In our efforts to practice this approach, we will provide an overview of four pedagogical experiments from two design schools, one in the USA and the other in Belgium, as a case study in trans-disciplinary problem-based design-thinking education.

\section{TWO CONTINENTS, TWO SCHOOLS, FOUR COURSES}

\subsection{Relationship and summary of two schools for case study}

Howest University College is located in Kortrijk, Belgium. Howest has a 3-year bachelor's programme in Industrial Product Design with 320 enrolled students and 29 faculty (in education and research). Appalachian State University is located in Boone, NC, USA. Appalachian State has a 4-year bachelor's programme in Product Design with 190 students and 9 faculty. Howest and Appalachian State have had an exchange relationship since 2012, with an ongoing semester abroad student programme.

\subsubsection{Rationale for comparison}

These two academic programmes are similar in many ways: both are pragmatic professional programmes, generating graduates that tend to go directly into industry. The programmes are distinct as a reflection of two different national academic cultures: Howest is a 3-year dedicated programme (in which students only follow courses in Product Design), while Appalachian State is 4-year liberal-arts degree programme (with students completing 89 credits out of 128 credits in Product Design). This creates many distinctions in how courses are structured, taught, and sequenced. These similarities and differences offer a unique opportunity to compare approaches to teaching trans-disciplinary courses.

\subsection{Two courses at Howest}

Table 1. Overview of two courses taught at Howest University College

\begin{tabular}{|c|c|c|}
\hline & WOW week (Fall 2018) & $\begin{array}{l}\text { Interdisciplinary design studio } \\
\text { (Spring 2018) }\end{array}$ \\
\hline $\begin{array}{l}\text { Course } \\
\text { Schedule }\end{array}$ & $\begin{array}{l}\text { 3-credit class, first week fall semester full } \\
\text { time, } 40 \text { hours of class time }\end{array}$ & $\begin{array}{l}\text { 30-credit studio class, full time for the whole } \\
\text { semester ( } 38 \mathrm{~h} / \text { week, } 16 \text { weeks) }\end{array}$ \\
\hline Students & 187 final year students & 12 final year students \\
\hline Teams & $\begin{array}{l}35 \text { teams of } 4-6 \text { students each, varied } \\
\text { disciplines }\end{array}$ & 1 team: $3 \times 4$ students for each discipline \\
\hline $\begin{array}{l}\text { Faculty\& } \\
\text { experts }\end{array}$ & $\begin{array}{l}2 \text { Co-Leaders: Industrial Design, } \\
\text { Communication Management. } \\
4 \text { Supporting Faculty: Recreation } \\
\text { Management, Physiotherapy, Graphic \& } \\
\text { Interaction Design, Social work. } \\
3 \text { external specialists/keynote speakers } \\
1 \text { cultural performer (theatre company) }\end{array}$ & $\begin{array}{l}6 \text { Faculty: } 2 \text { Industrial Product Design, } 2 \\
\text { Graphic \& Interaction Design, } 2 \text { Digital Arts } \\
\text { \& Entertainment. } \\
1 \text { project manager (industrial design) } \\
50 \text { staff (teaching/research) on voluntary base, } \\
\text { whenever they want to spend some time. }\end{array}$ \\
\hline Projects & $\begin{array}{l}1 \text { project owner (city of Kortrijk), } 1 \\
\text { general challenge, } 7 \text { sub-challenges. Social } \\
\text { (society) sustainability }\end{array}$ & $\begin{array}{l}1 \text { challenge from international company ('18: } \\
\text { Volkswagen). Open challenge }\end{array}$ \\
\hline $\begin{array}{l}\text { Design } \\
\text { Thinking } \\
\text { Methodology }\end{array}$ & $\begin{array}{l}\text { 5-step design thinking flow (each day with } \\
\text { another focus: empathise, inspire, create, } \\
\text { make/test, present) }\end{array}$ & $\begin{array}{l}\text { In-house developed design thinking process } \\
\text { and strategy }\end{array}$ \\
\hline
\end{tabular}

\subsubsection{WOW Week (4 iterations)}

\section{Unique aspects of this class:}

- Wow week challenges final year Howest students to co-design solutions for a local organisation with local people as beneficiaries. The possibility to interact one on one is key.

- external keynote speakers present on Monday about their expertise ('18: mobility). 3 Howest speakers do the same, but about their expertise in open project organisation. 1 cultural performance related to the topic ('18: 'eye feed', Baltaljong - theatre company) is organised, on Monday evening.

- $\quad$ Meeting space: external event hall, neutral to all students and faculty, access from 8 AM till 8 PM. Methods utilised

5-Day Design Thinking structure developed internally (by Dries Laperre and Lieven De Couvreur). 


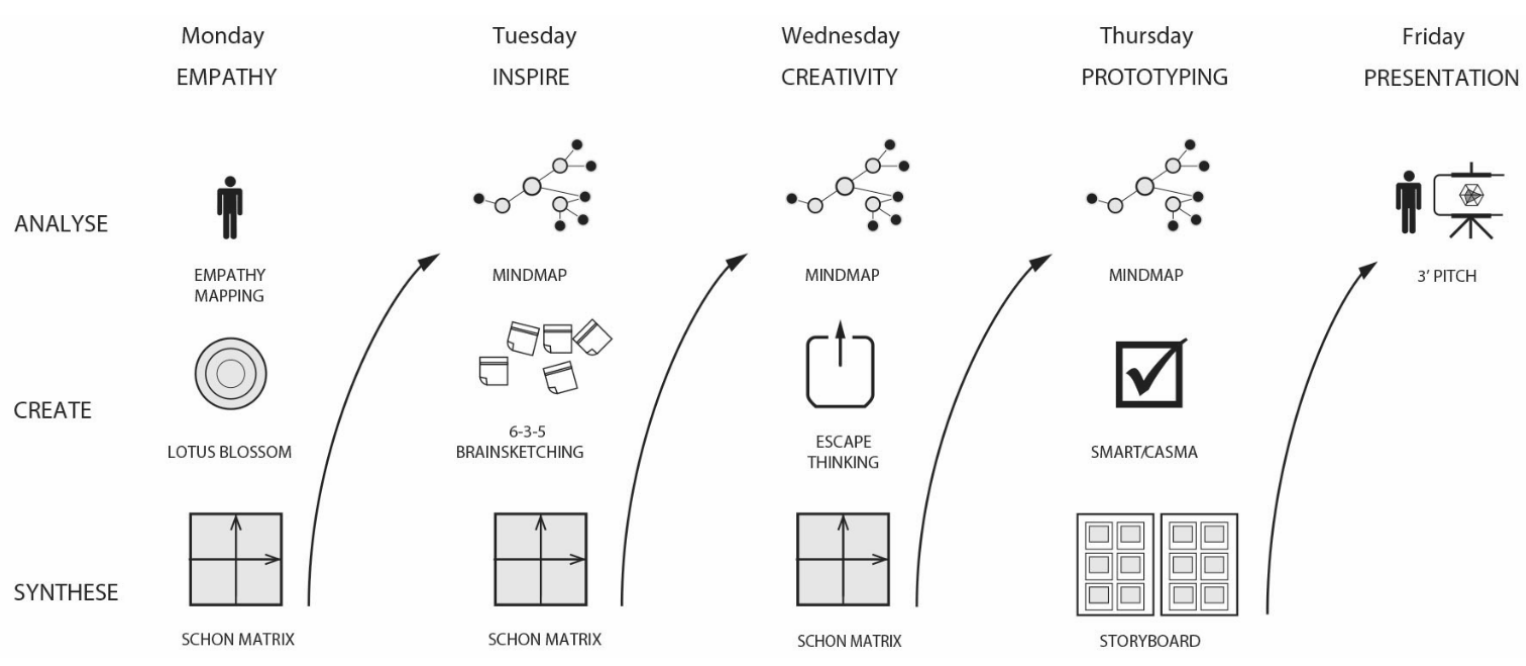

Figure 1. Design Thinking structure and methods utilised for WOW Week

To help guide students with less experience in Design Thinking, and to align teams to a focused task, worksheets developed in-house for creativity and team communication were available, but not obligated: INNOWIZ template set, Howest 2017.

\subsubsection{Interdisciplinary Design Studio - the collective (first iteration): Unique aspects of this class:}

- Students were $100 \%$ in command of the project: they decided about organisation, planning, budget, how to present and deliver. They made a self-steering team, only coached - not lead by faculty/staff.

- Students have to apply for this course since numbers are limited. They worked full time for 1 full semester with 12 students from 3 disciplines.

- Organised in neutral co-creation office in between other companies (https://www.hangark.be/), providing office desks, meeting rooms, brainstorm rooms, copy office and coffee. Students were welcome on all network-events, informal (lunch) meetings and inspiring excursions. Possibility to use all infrastructure and tools accessible for students Howest.

- The challenge came from a multinational with a well-known brand and high-level reputation. In 18 Volkswagen was the client.

\section{Methods utilised}

Product Design Methodology developed internally (by Dries Laperre and Lieven De Couvreur).

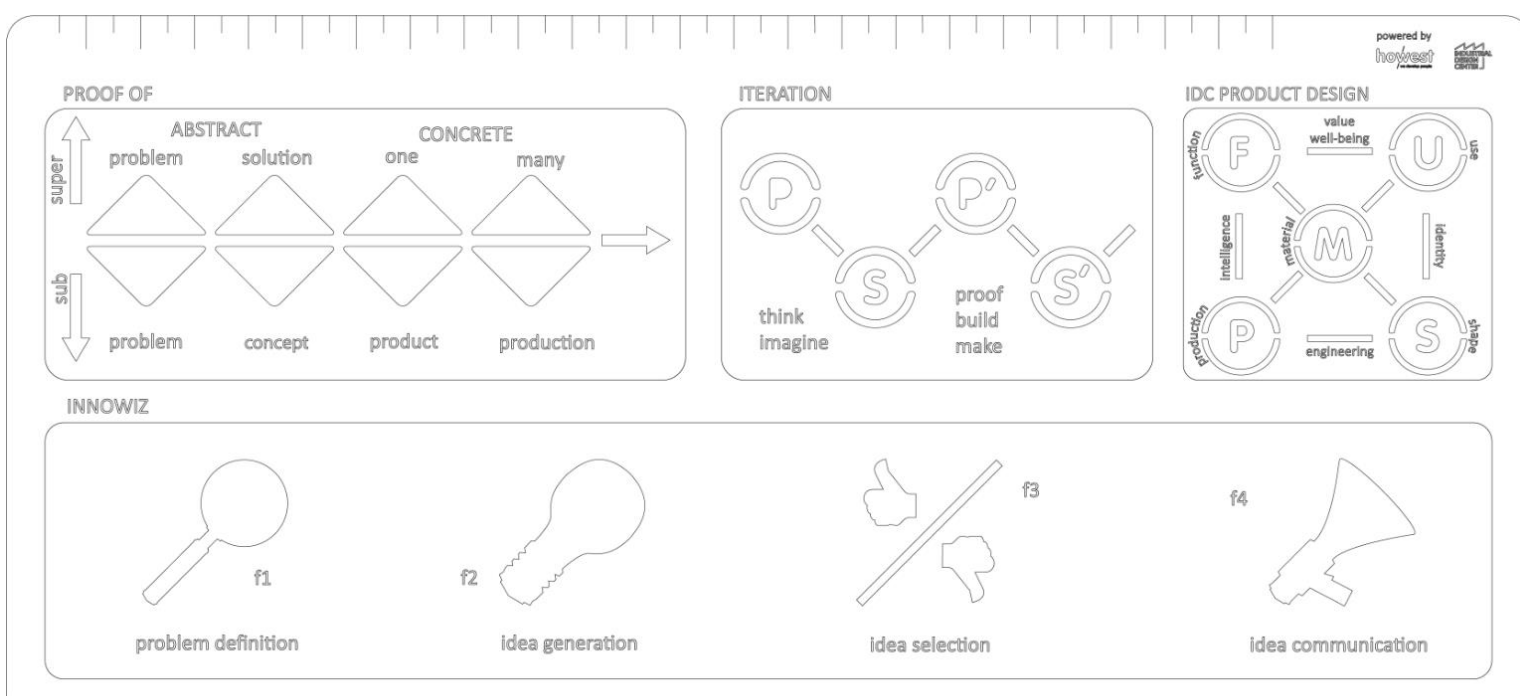

Figure 2. Design Thinking structure and methods utilised for 'the collective' 


\subsection{Two courses at Appalachian State}

Table 2. Overview of two courses taught at Appalachian State University

\begin{tabular}{|l|l|l|}
\hline \multicolumn{1}{|c|}{ AppLab (Fall 2017) } & \multicolumn{1}{c|}{ Thinkering (Spring 2018) } \\
Schedule & $\begin{array}{l}\text { 6-credit class, met 6 hours/week (MWF, } \\
\text { 12-2pm), 96 hours of class time }\end{array}$ & $\begin{array}{l}\text { 3-credit studio class, met for 6 hours/wk., } \\
\text { (MWF, 12-2pm), 96 hours of class time }\end{array}$ \\
\hline Students & $\begin{array}{l}\text { 30 students, 6-8 from each } \\
\text { college/department participating }\end{array}$ & $\begin{array}{l}\text { 12 students from Industrial Design, Studio } \\
\text { Art, Graphic Design, Computer Science, } \\
\text { Business, Dance and Psychology }\end{array}$ \\
\hline Teams & $\begin{array}{l}\text { 7 teams of 4-6 students each, varied } \\
\text { disciplines }\end{array}$ & 4 teams of 3 students each, varied disciplines \\
Experts & $\begin{array}{l}\text { 6 Faculty. 2 Co-Leaders: Industrial } \\
\text { Design, Management. 4 Supporting } \\
\text { Faculty: Recreation Management, } \\
\text { Leadership Studies, Education, Health } \\
\text { Sciences. } \\
\text { 1 Client representative from each project. }\end{array}$ & $\begin{array}{l}\text { 6 Faculty: Industrial Design (3), } \\
\text { Metalsmithing, Graphic Design, MakerSpace }\end{array}$ \\
\hline $\begin{array}{l}\text { Projects } \\
\text { projects, 1 per team: 5 external client } \\
\text { internal projects }\end{array}$ & Self-defined by each team. \\
\hline $\begin{array}{l}\text { Design } \\
\text { Methodology }\end{array}$ & $\begin{array}{l}\text { 7-step design thinking methodology (more } \\
\text { details below) }\end{array}$ & 7-step design thinking methodology \\
\hline
\end{tabular}

\subsubsection{AppLab (4 iterations)}

\section{Unique aspects of this class:}

- $\quad$ Focuses on developing 'soft skills' of collaboration, perseverance, adaptability, grit. Faculty from Leadership Studies helped with this and a focus on team-building.

- Began with 2-day design-intensive at IBM Design Centre in Durham, NC. This connection to the professional community helped energise the teams and demonstrate relevance.

- Utilised a unique meeting/event space in a shared-use off-campus facility. This was a neutral space, not under the control of one discipline. Students had 24/7 access to meet with teams/clients.

- Each team was assigned a client and given a general design brief. It was up to the teams to define their specific challenge through research.

\section{Methods utilised}

A seven-step Design Thinking structure was used.

Table 3. Overview of 7-step structure and specific methods applied at each step (developed internally by Mark Lewis and Richard Elaver

\begin{tabular}{|c|c|c|}
\hline Step & Title & DT Tools/methods \\
\hline 1 & Define the Challenge & $\begin{array}{l}\text { Boundary Examination, Fishbone, Morphological Analysis, 5W1H, } \\
\text { Project Sheet, Design Brief Template }\end{array}$ \\
\hline 2 & Discover Your World & $\begin{array}{l}\text { Macro-Level Analysis: Environmental Map } \\
\text { Meso-Level Analysis: Business Model Canvas, Process Modelling } \\
\text { Micro-Level Analysis: Customer Journey Mapping, Customer Profile } \\
\text { Mapping, Empathy Mapping, Interviews, Observation }\end{array}$ \\
\hline 3 & $\begin{array}{l}\text { Isolate Issues and } \\
\text { Opportunities }\end{array}$ & 'How Might We...' questions, Multi-voting, Matrix Evaluation \\
\hline 4 & Ideate to Consider & Brain Sketching Pool, Affinity Mapping, Multi-voting, 9 Windows \\
\hline 5 & Incubate to Explore & 'Get out there' assignment to diversify student experience \\
\hline 6 & Prototype to Refine & Storyboards, physical models, sketches/illustrations \\
\hline 7 & Test to Iterate & Presentation of final concept and prototypes \\
\hline
\end{tabular}

Where possible, worksheets were used to help guide students with less experience in Design Thinking, and to align teams to specific outcomes. Many of those worksheets, e.g. Morphological Analysis and 5W1H, were developed by the INNOWIZ team at Howest University College. 


\subsubsection{Thinkering}

Unique aspects of this class:

- Each team defined their own subject and project based on a prompt with the following requirements: 1) Technical simplicity, 2) Provide social benefit, 3) Facilitate distributed manufacturing, 4) Result in two identical prototypes.

- The social aspect of the group project was key to getting student buy-in for the project.

- A dual-schedule structure was used to coordinate both the accumulation of skills, and the application of those skills to a semester-long project. Student teams engaged in semester-long project, addressed 1 day per week, structured around a 7-step Design Thinking methodology. Meanwhile, students participated in skill-building workshops 2 days/week. The workshops were arranged along four tracks, so each team accumulated a diverse set of skills among its members.

\begin{tabular}{|c|c|c|c|c|c|}
\hline \multicolumn{6}{|c|}{ Thinkering Schedule } \\
\hline Module & Week & Module Content & & & \\
\hline \multirow{3}{*}{1} & 1 & \multirow{3}{*}{\multicolumn{4}{|c|}{ 3D CAD - Intro to Rhino (all students) }} \\
\hline & 2 & & & & \\
\hline & 3 & & & & \\
\hline \multirow[t]{2}{*}{2} & 4 & \multicolumn{4}{|c|}{ Intro to 3D Printing (all students) } \\
\hline & 5 & & & & \\
\hline & & \multicolumn{4}{|c|}{4 Tracks: one student from each team per track } \\
\hline & & 1) Analog & 2) Vector & 3) 3D & 4) Physical Computing \\
\hline \multirow[t]{2}{*}{3} & 6 & \multirow[t]{2}{*}{ Metal Machining } & \multirow[t]{2}{*}{ Adobe Illustrator } & \multirow[t]{2}{*}{ Adv.3D printing } & \multirow[t]{2}{*}{ Basic Electronics } \\
\hline & 7 & & & & \\
\hline \multirow[t]{2}{*}{4} & 8 & \multirow[t]{2}{*}{ Mold-making } & \multirow[t]{2}{*}{ Vector-cutting } & \multirow[t]{2}{*}{ Intro $2 D C N C$} & \multirow[t]{2}{*}{ Arduino } \\
\hline & 9 & & & & \\
\hline \multirow{2}{*}{5} & 10 & \multirow[t]{2}{*}{ Finishing } & \multirow[t]{2}{*}{ CNC 2D } & \multirow[t]{2}{*}{ CNC 3D } & \multirow[t]{2}{*}{ E-Textiles } \\
\hline & 11 & & & & \\
\hline 6 & 12 & Graphics and Con & munications(alls & tudents) & \\
\hline \multirow{4}{*}{7} & 13 & \multirow{4}{*}{\multicolumn{2}{|c|}{ Final Project Time }} & & \\
\hline & 14 & & & & \\
\hline & 15 & & & & \\
\hline & 16 & & & & \\
\hline
\end{tabular}

Figure 3. Thinkering course dual schedule

\section{CONCLUSIONS REGARDING POSITIVE AND NEGATIVE OUTCOMES}

\subsection{Shared Lessons Learned}

1. Even though teams in these courses start out having a flat hierarchy, the design students tend to be viewed as the team leader or facilitator. Interestingly, this happens both with the students and the faculty - others look to the designers to lead. This is coupled with observational experience of watching student teams without a design student falter and struggle in the process. Design students are not trained to be team leaders/managers. However, they tend to be willing to take initiative and jump into the open-ended process. Plus, they do have some experience in Design Thinking, which is a central part of each of these courses, so it makes sense that they might have a unique role in facilitating that process. There is something here to be explored in the future regarding team structure and hierarchy.

2. Some of the greatest benefits for students participating in these courses are soft skills that are more challenging to measure. Still, it is clear that this type of experience presents best practices to prepare students for real teamwork in a professional environment, as they are working across significant disciplinary boundaries. From this, students express being more empowered to take on larger, less-defined challenges. Being connected to real-world challenges, they see themselves as agents of change in the world and are motivated to participate. Students' skills for working with others, dealing with ambiguity, and persevering through challenges are clearly enhanced.

3. The focus of these course experiences is to better prepare students for the professional world, not to necessarily provide professional consulting work. This can be challenging to communicate to internal administrators and professional clients. Academic administrators want to see a 'win' and have evidence in the marketplace of 'success'. And professional clients want a bargain - a low- 
cost return on investment, where students solve their problems. However, the real value is in the experience, both for the students and the clients. Companies get significant value from the work that students do, though it may not be complete or fully refined in the end. And students, while learning to be professionals, develop their skills in a hybrid academic-professional environment.

4. Location for these types of learning experiences is critical. For the Volkswagen project, students were located in an off-campus facility, surrounded by other professionals. In school, students feel like students, in the professional working space, they feel and behave more professionally. Similarly, in the AppLab class, students were in a unique off-campus work space. This helped avoid issues of ownership (among faculty and administrators) and positioned the students to be more focused. It seems that standard classroom space is not conducive to creating these types of learning experiences.

5. Creating these types of experiences present significant organisational design challenges. Institutional structures matter, and they are insidious. Structurally, the different schedules in different departments makes it a challenge to engage students and faculty. Culturally, departments vary considerably, as do expectations of students, work ethic, sense of ownership, willingness to take risks, etc. This all adds to the challenge of working together effectively. This is true for students as well as faculty. Faculty tend to stay in their comfort zones and within their areas of expertise.

6. Evaluation was a significant challenge for all of these projects. Different faculty have different interpretations regarding the metrics used. Faculty from different areas wanted to look after their students and protect their grades relative to the teams. It seems that this needs to be more clearly defined at the outset of the class, with agreement among the faculty, in order to maintain more objective grading and student evaluation.

7. Appropriately defining the design challenge and desired outcomes is critical to success. From experience, leaving the problem too broad, and expecting student teams to define their own challenge, tends to get complicated and consumes a great deal of time. On the other extreme, being too narrow with the problem denies students the opportunity to discover and define their own challenges and decreases intrinsic motivation among students. So, framing a problem within a set of parameters that increase the likelihood of student success is key.

8. The networking from these experiences is important for students in their academic and professional lives. Through their team connections, they develop strong relationships and connect with students from other concentrations. This also happens with faculty collaborating in these experiences. Those connections are valuable for future collaborations and communications.

9. At some point efficiency takes over from adventure. These efforts can be exciting to start, but difficult to sustain. Like a new business, seed capital may be forthcoming, but sustaining through growth challenges into maturity is more challenging. Similarly, administrators may be supportive of a new initiative in year one but may expect the effort to continue in future years without additional resources or incentives. Faculty, too, may be excited to develop new content in year one, but may grow bored as the programme repeats. This is an important issue with these types of courses because of the coordination costs - content can become more efficient and streamlined, but coordination of faculty, students, and clients/projects continues to demand extensive effort. We have presented a range of courses regarding this development over time. The VW and Thinkering projects were new, with no established structure, and developed on-the-fly. AppLab, has become somewhat established after four iterations in five years, but may not continue. AppLab faculty have fatigued of the coordination costs, and administrative support has waned over time. WOW Week, by contrast, has become established after four iterations in as many years. It has strong institutional support and a refined efficient structure and is expected to continue in the coming years.

\section{REFERENCES}

[1] Hora M.T. Beyond the Skills Gap, National Association of Colleges and Employers. Available: https://www.naceweb.org/career-readiness/trends-and-predictions/beyond-the-skills-gap/ [Accessed on 2019, 11 March] (Year Created: 2017, 01 February). 